\title{
ESTRANHAMENTO COMO ESTRATÉGIA DE TRADUÇÃO: CATEGORIZAÇÃO DO ESTRANHAMENTO NA POESIA LEMINSKIANA E A SUA RECRIAÇÃO NA LÍNGUA CHINESA
}

\author{
Sida Lang1 \\ Yuqi Sun 1 \\ ${ }^{1}$ Universidade de Macau, Macau, China
}

\begin{abstract}
Resumo: Paulo Leminski é visto como poeta de vanguarda que até hoje continua a exercer forte influência nas novas gerações de poetas brasileiros. Neste artigo, discutimos o estranhamento na poesia leminskiana e a sua recriação na tradução em chinês. Após a discussão da conotação do estranhamento no contexto da tradução literária, elaboramos uma categorização inédita do estranhamento consistente de seis categorias e mostramos o processo de recriação do estranhamento exemplificado com traduções. Defendemos que uma categorização adequada pode ajudar na recriação do estranhamento, servindo como estratégia orientadora da tradução poética. O próximo passo para a pesquisa em recriação do estranhamento consistirá, segundo acreditamos, de estudos e/ou traduções aplicando a categorização em outras obras literárias e melhorando a própria categorização.

Palavras-chave: Estranhamento; Categorização; Tradução Poética; Paulo Leminski
\end{abstract}

\section{ESTRANGEMENT AS TRANSLATION STRATEGY: CATEGORIZATION OF ESTRANGEMENT IN PAULO LEMINSKI'S POEMS AND ITS RE-CREATION IN CHINESE}

Abstract: Paulo Leminski is considered avant-garde who continues to exert a strong influence on the new generations of Brazilian poets. In this article, we discuss the estrangement in Leminski's poems and its re-creation 
in Chinese translation. After discussing the connotation of estrangement in the literary translation context, we develop an unprecedented categorization of estrangement consisting of six categories and present our definition of criteria for the categories as well as the estrangement re-creation process exemplified by translated poems from Portuguese to Chinese. We believe that serving as a guiding strategy for poetry translation, a proper categorization can help with the re-creation of estrangement. The next step for research into the re-creation of estrangement will consist, as we see, of studies and/or translations applying the categorization in other literary works and improving the categorization itself.

Keywords: Estrangement; Categorization; Poetry Translation; Paulo Leminski

\section{Introdução}

O conceito de estranhamento foi formalmente definido pelo formalista russo Chklovski em 1917, mesmo já sendo conhecido muito antes de ganhar essa definição. Foi definido como "procedimento da singularização dos objetos e o procedimento que consiste em obscurecer a forma, aumentar a dificuldade e a duração da percepção" (Chklovski 45), distanciando o leitor do modo comum como apreende o mundo e a arte.

Os seus primórdios podem até remontar a Aristóteles que aponta a natureza espantosa da tragédia (Gazoni 115). Desde sempre, "o surpreendente", "o assombro" e "o espantoso" têm sido abordados por poetas, escritores e teóricos literários, incluindo Dionísio Longino (século III), (Várzeas 16), Jacopo Mazzoni (século XVI) (Wu 201) e Ludovico Antonio Muratori (92-93). Nos séculos XVIII e XIX, a contribuição epistemológica romântica marcou uma viragem na evolução do conceito de estranhamento. O escritor romântico Novalis tentou, pela primeira vez, uma definição formal do conceito de estranhamento (Robinson 79) enquanto Wordsworth (Wordsworth and Coleridge i-ii) e Coleridge (442), na passagem dos séculos XVIII e XIX, buscavam produzir o efeito de estranhamento nas suas obras. Já mais próximo à contemporaneidade, o idealismo alemão exerceu uma influência direta na formação do 
conceito. Após a denominação por Chklovski em 1917, o estranhamento (em russo, ostranenie) foi traduzido para várias línguas.

É de sublinhar que, o tal conceito literário, mesmo já sendo um tópico abordado por muitos estudiosos, até o presente momento ainda não foi sistematicamente analisado no âmbito da tradução literária português-chinês. Quando colocada no âmbito da tradução literária, a conotação do estranhamento tornar-se-á mais complicada do que quando tratada dentro da mesma língua. Assim, surgiram-nos as perguntas iniciais, a saber: como se pode entender o estranhamento no contexto da tradução literária? Será possível a recriação do mesmo na tradução literária, em específico, na tradução da poesia?

Ao fazermos leituras poéticas dos autores de língua portuguesa, um eminente poeta de vanguarda brasileiro pareceu-nos aproximarse da nossa noção de estranhamento. Trata-se de Paulo Leminski, poeta curitibano que tentava criar uma linguagem própria e experimental em seus poemas. A sua aventura linguística e estilística faz com que os seus poemas sejam repletos de novidades e surpresas, que mostram justamente o efeito de estranhamento em vários aspectos. Sendo assim, ocorreu-nos a ideia de analisar o fenomeno de estranhamento a partir da poesia leminskiana, com o objetivo de propor uma categorização para o estranhamento e aplicá-la na nossa tradução de seus poemas do português para o chinês.

\section{Interpretação do estranhamento: dois contextos, duas dimensões}

No contexto literário, o estranhamento pode ser interpretado em duas dimensões. Em sua dimensão subjetiva, é um procedimento artístico que possui um carácter intencional, criado pelo autor através de certas técnicas de linguagem, para desfamiliarizar o seu leitor e despertar-lhe uma sensação de surpresa. Isto poderia distanciar o leitor da perspectiva comum em que olha a arte, possibilitando-lhe uma experiência de rever o mundo à volta já familiar. 
Citamos palavras de Chklovski (45) que complementam a nossa definição:

O objetivo da arte é dar a sensação do objeto como visão e não como reconhecimento; o procedimento da arte é o procedimento da singularização dos objetos e o procedimento que consiste em obscurecer a forma, aumentar a dificuldade e a duração da percepção.

Em dimensão objetiva, o estranhamento é um resultado causado ao receptor, um efeito artístico visado criar impacto espantoso. No entanto, o efeito pode não ser percebido logo que o leitor o receba. O receptor precisa de mais esforço cognitivo para refletir. Quando ultrapassar o obstáculo da percepção (mesmo parcialmente), ganha o momento de surpresa; quando encontrar demasiada dificuldade, o receptor ficará afastado do momento de surpresa.

Mesmo sendo abordado muitos anos antes, só até 1917 foi formalmente concretizada a conotação do estranhamento. Foi denominado como "ostranenie" pelo formalista russo Chklovski (1893-1984) no seu trabalho publicado "A arte como procedimento ". Traduzido depois para várias línguas, começou a ganhar nomes diferentes, como em inglês "estrangement" "defamiliarization", "deformiliarzation" "deformiliarization"; em português, "estranhamento", "desfamiliarização" e "singularização"; em chinês, “陌生化 (mò shēng huà)" “反常化(făn cháng huà)” “奇异化(qí yì huà)”, etc.. Entre eles, “estranhamento”, “estrangement” e “陌生化 (mò shēng huà)" são mais utilizados nas referências bibliográficas que consultamos. Tendo o português como a língua de escrita deste artigo e, a fim de evitar confusão no uso dos termos, adoptamos "estranhamento" para nos referir a tal conceito em geral enquanto "ostranenie" ao estranhamento de Chklovski.

O estranhamento, quando colocado no contexto da tradução literária, a sua conotação torna-se mais complicada. Vejamos ainda nas duas dimensões explicadas: Em dimensão objetiva, duplicará 
o passo de recepção (PR), ou seja, um procedimento criado pelo poeta passa primeiro ao tradutor e depois vai ao leitor da língua alvo (LA). Em dimensão subjetiva, duplicará o passo de criação (PC), isto é, um procedimento de estranhamento criado pelo poeta necessitará ser recriado pelo tradutor. Tal como se mostra abaixo na figura 1, há 4 resultados que poderão aparecer, a saber: 1) o procedimento criado pelo poeta não consegue chegar ao tradutor e, portanto, jamais ao leitor da LA; 2) o procedimento recriado é recebido pelo tradutor, mas não é (re)criado e, naturalmente, não chega ao leitor; 3 ) o procedimento criado é recebido e (re)criado pelo tradutor, passando ao leitor, mas não é recebido pelo último; 4) o resultado ideal: o procedimento criado é recebido e (re)criado pelo tradutor e, enfim, chega e é entendido pelo leitor da LA. Nesse caso, podemos dizer que o leitor recebe "o momento de surpresa".

Figura 1: Resultados possíveis da recriação do estranhamento

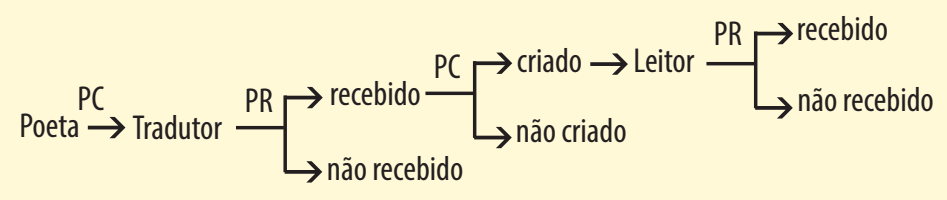

Fonte: As autoras

Portanto, é exatamente este processo de "recepção-(re)criação" do tradutor que complica a transmissão do estranhamento no contexto da tradução. Cabe realçar, no processo de (re)criação do tradutor, pode acontecer que um procedimento existente na língua fonte (LF) não seja recriado no processo de tradução, assim o leitor da língua alvo (LA) perderá a oportunidade de se "estranhar". Ou, um procedimento não existente no texto fonte (TF) é criado no texto alvo (TA). Sendo assim, o leitor corre risco de ter uma ilusão causada pela tradução, considerando-a como TF. Quanto ao tradutor-leitor, esse desempenha um papel prestável e perigoso, como se fosse jogador de xadrez no processo de perda-ganho. Por um lado, 
corre o risco de não receber o estranhamento da LF, e por outro, assume a responsabilidade de recriá-lo na LA. A nosso ver, tradução não é transformação de palavras de uma língua para outra, nem capricho de criação na LA. Para o tradutor, a recriação do procedimento de estranhamento não é uma questão de possibilidade, mas é de grau, uma vez que demasiadas perdas do estranhamento prejudicam a literariedade da obra original, enquanto excessivas estranhezas poderão afastar o leitor. O estranhamento na tradução pede sempre moderação. Sendo assim, a árdua tarefa do tradutor é, na verdade, manter um equilíbrio entre perdas e ganhos. É criar o semelhante impacto estético no leitor da LA como da LF. Isso talvez nos leve à "equivalência dinâmica" de Nida (159), defendendo que a tradução de qualidade seria aquela que causasse no leitor o mesmo efeito causado nos leitores da obra original. Esse princípio de medir uma tradução fará sentido se tivermos como objetivo a recriação do efeito de estranhamento. No entanto, "o mesmo efeito" trata-se do sentido relativo, já que a expectativa e a experiência prévia variam de leitor para leitor.

Quanto à conotação do estranhamento na tradução, vale a pena distinguir aqui dois termos: estranhamento e estrangeirização. Começamos pelo conceito de estrangeirização, desenvolvido juntamente com o conceito de domesticação por Lawrence Venuti (20). O autor fundamentou a sua busca pela visibilidade do tradutor e pela diversidade cultural nos dois princípios lançados por Schleiermacher ${ }^{1}$ acerca dos métodos de tradução. No seu juízo, a tradução estrangeirizante que dificulta a legibilidade do texto traz uma experiência "alien" de leitura, deslocando o leitor em direcção ao autor, enquanto a tradução domesticante naturaliza o discurso do autor, deslocando-o em direcção ao leitor. Por suas palavras:

\footnotetext{
1 "Ou bem o tradutor deixa o escritor o mais tranquilo possível e faz com que o leitor vá a seu encontro, ou bem deixa o mais tranquilo possível o leitor e faz com que o escritor vá a seu encontro" (Schleiermacher - tradução de Heidermann 57-58).
} 
... Schleiermacher allowed the translator to choose between domesticating method, an ethnocentric reduction of the foreign text to target-language cultural values, bringing the author back home, and a foreignizing method, an ethnodeviant pressure on those values to register the linguistic and cultural difference of the foreign text, sending the reader abroad (Venuti 20).

Venuti (20) acrescenta que a estrangeirização significa quebrar os cânones da LA e desenvolver uma teoria e prática de tradução que resiste aos dominantes valores culturais da LA, para que se nota a língua e a cultura do TF.

Daí, combinando com a conotação do estranhamento, resumimos a diferença entre os dois termos como: 1) O estranhamento tem a sua origem na literatura, mas a ela não restringe, podendo entrar também em áreas como psicologia, arte, cultura, estética, tradução, etc., mas a estrangeirização existe apenas na tradução; 2) No contexto da tradução, consideramos a estrangeirização como uma força orientadora enquanto o estranhamento, além de ser estratégia e método de tradução, refere-se ainda ao resultado do mesmo efeito; 3) $\mathrm{O}$ estranhamento pode existir tanto no TF como no TA. Por um lado, é o que o autor original cria para produzir ao seu leitor estranheza e surpresa, por outro, o que o tradutor recria para estranhar o leitor da LA. No entanto, a estrangeirização pertencente apenas ao TA, podendo causar impedimento para leitura e entendimento do leitor da LA, em vez da LF.

Cumpre destacar ainda que o estranhamento, sendo um fenômeno complexo, acontece na base de uma experiência prévia, através de um procedimento que pode causar o seu efeito a uma pessoa, mas a outra, talvez não. A estrangeirização, porém, oposta à domesticação, baseia-se na aproximação da estrutura, gramática e cultura da LF. Sob essa força orientadora, uma tradução pode, mas não necessariamente, produzir efeito de estranhamento. 


\section{Estranhamento na poesia de Paulo Leminski}

Paulo Leminski (1944-1989), poeta de vanguarda, escritor, professor, tradutor e cancionista, deixou uma obra de poesia marcante que tem influenciado diversos movimentos poéticos das últimas décadas. O livro Metaformose foi o ganhador do Prémio Jabuti de Poesia em 1995. Um poema "Sintonia para pressa e presságio" foi incluído no livro Os Cem Melhores Poemas Brasileiros do Século (Moriconi). O estilo da escrita poética de Leminski foi influenciado principalmente pelo contato com o Concretismo, o Tropicalismo, o interesse pela cultura japonesa e duas ditaduras. Todos estes elementos se comunicam sob a sua própria criatividade, ambição e humor, caracterizando a poesia leminskiana.

O jovem Leminski vivenciou a ascensão do Concretismo, quando passou a ter várias tendências pós-concretistas, em que está o Tropicalismo. Consequentemente, é fácil encontrar traços da poesia concreta na sua obra poética, tais como a decomposição das palavras, a eliminação do verso, a exploração do conteúdo sonoro e semântico dos vocábulos, o aproveitamento de todo o espaço da página para a disposição das palavras, frases ou caracteres, e para a utilização de efeitos gráficos. Podemos dizer que o Concretismo contribuiu para a característica visual da poesia leminskiana. Além disso, Leminski bebeu na fonte da Tropicália que contribuiu para a musicalidade, oferecendo-lhe um novo suporte além do livro. Tal como ele confessou: “... o centro da poesia se deslocou do livro para a música popular... Com a geração que produziu Caetano e Chico, viu-se deslocar o pólo da poesia, do suporte livro para o suporte disco" (Leminski, (a) 28). Nesse movimento tropicalista, o poeta curitibano e os seus contemporâneos procuravam articular uma nova linguagem a partir da Música Popular Brasileira (MPB) e dos diversos elementos que a modernização oferece (Favaretto 32-33). Como mostra a seguir o poema de Leminski ((F) s/p): 


\section{Tudo \\ que \\ li \\ me \\ irrita \\ quando \\ ouço \\ rita \\ lee}

Vê-se obviamente a convergência da poesia e música popular. O rigor formal e a musicalidade interatuam no trocadilho ("li irrita" e o nome da cantora brasileira "rita lee"). Esse potencial musical da sua poesia tornou vários poemas em canções. O "Verdura" serve de melhor exemplo, gravado por Caetano Veloso e apresentado como oportunidade de chamar atenção a temas urgentes e de reservar memória do seu tempo.

Mais do que o Concretismo e o Tropicalismo, também o haicai ${ }^{2}$ japonês marca poemas de Leminski. Aproveitando-se da concisão desta forma poética, a poesia leminskiana é mais do que a "brevidade", destacada ainda pela "exatidão" (Marques 93). O poeta brasileiro também se aproveitou da figura do kakekotobá, combinação da aliteração e assonância. Por palavras de Leminski ((C) 39), o kakekotobá é “. . . a passagem de uma palavra por dentro de outra palavra, nela deixando seu perfume. Sua lembrança. Sua saudade”. O poema seguinte pode servir de exemplo:

isso sim me assombra e deslumbra como é que o som penetra na sombra

e a pena sai da penumbra? (Leminski, (E) 77)

\footnotetext{
2 Também chamado de "haiku” ou "haicai” (em japonês, “俳句”), é uma forma poética tradicionalmente consistente de 17 on (sílabas japonesas) em três versos de 5, 7 e 5 on respectivamente, sem título nem rima. É destacada pela objetividade, cujos temas mais explorados são referentes à natureza e ao quotidiano, e contém nele normalmente um kigo, termo que implica a estação do poema.
} 
Pode-se ver o movimento da palavra "som" nas palavras "assombra" e "sombra" nos primeiros versos, e a passagem da palavra "pena" nas "penetra" e "penumbra". Ademais, os três versos rimam-se e estão ligados à natureza. Mesmo que fosse seguidor do haicai, Leminski não ficou preso à tradição japonesa. Nos seus haicais, raramente se apresentam os tradicionais 17 on. Ele preferia a forma livre do terceto e criou uma forma oriental abrasileirada, o seu "quase-haicai". Vejamos um exemplo:

\section{Duas folhas na sandália \\ O outono}

Também quer andar (Leminski, (F) s/p.)

De acordo com as regras da contagem das sílabas métricas ${ }^{3}$, o primeiro verso tem sete sílabas poéticas (Du/as fo/lhas/ na /san/dá/ lia), o segundo tem duas sílabas poéticas (O ou/to/no) e o último tem cinco (Tam/bém/ quer/ an/dar). É óbvio que o quase-haicai leminskiano, por um lado, não tem muito de ortodoxo japonês no rigor rítmico, por outro, mantém uma ligação com o zen-budismo, por palavras de Leminski, “. . . a escrita japonesa dos haicais tende para o estado gasoso, a rarefação, a dissolução da matéria, sempre a um terço do ponto onde se fixa, mas não se define" ((G) 72).

As propriedades visuais, musicais e orientais não são todas as características da poesia leminskiana. Não se pode esquecer a sua noção histórica. Vivia de uma forma intempestiva sob o regime arbitrário da ditadura militar brasileira, a obra poética de Leminski mantém uma relação íntima e subtil com a postura política. Poeta é quem nasce com a sensibilidade para o mundo à volta e sabe comunicar com a linguagem poética. O seguinte poema já é testemunho da realidade da sua época:

3 Fabre, Mardilê Friedrich. "Contagem das sílabas poéticas." Recanto das Letras. 21 mar 2013. web. 31 mar 2019 < https://www.recantodasletras.com.br/ teorialiteraria/254742> 


\author{
ameixas \\ ame-as \\ ou deixe-as (Leminski, (B) s/p)
}

À primeira vista, o quase-haicai escrito nos anos 60 é simples, em que se aplica a figura do kakekotobá, tirando de uma palavra ("ameixas") outra palavra ("ame-as") e compondo uma palavra ("deixa-as") a partir da outra ("ameixas"). No entanto, esta concisão contém muito mais informações, podendo causar o estranhamento a quem toma conhecimento da ditadura brasileira. Segundo Salgueiro (231), Leminski faz uma paródia do slogan "Brasil: ame -o ou deixe-o" propalado pela ditadura. Com cuidadosa construção do chiste, o poeta escolhe uma fruta não autóctone, referindo à época histórica cheia de ufanismo e xenofobia, imposta pelo regime militar. A partir de outro significado de ameixa (bala das armas de fogo), o estudioso revela ainda outra interpretação que “. . . o poema parece dizer, sob a capa chistosa, de uma história dividida entre os que querem a guerra, (e aqui se obnubila a diferença esquerda/direita), e os que não" (Salgueiro 232). Neste haicai, também é fácil sentir que o humor não lhe despojou a despeito da sensibilidade histórica e do afrontamento das formas de poder.

Portanto, parece-nos necessário realçar esta faceta da sua poesia: o humor leminskiano. Reside na sua dicção com uma linguagem acessível, nos trocadilhos, no jogar com ditados populares até nos palavrões. O poema "merda e ouro" é um exemplo tão adequado que já não precisa de mais explicação:

Merda é veneno.

No entanto, não há nada

que seja mais bonito

que uma bela cagada.

Cagam ricos, cagam padres

cagam reis e cagam fadas.

Não há merda que se compare

à bosta da pessoa amada. (Leminski, (d) s/p) 
Tendo analisado essas características vívidas, podemos sintetizar que a poesia de Leminski engloba o concretismo, o tropicalismo, o exotismo, o pós-modernismo e, finalmente, a cavalo da poesia concreta, o cavaleiro curitibano conseguiu chegar ao que lhe interessa: a sua poesia (Leminski and Bonvicino 63). Tal escrita, para um leitor que nada sabe da poesia concreta, é fácil suscitar estranheza; para quem já toma conhecimento do concretismo, oferecerá outras novidades. Aquele que está familiar com o haicai japonês vai aperceber-se da singularidade do quase-haicai leminskiano; caso não interessado nessa faceta, ainda poderá receber surpresas criadas pela sua mágica linguística. Graças à linguagem coloquial, ao tom humorístico e à vontade de comunicar com o seu leitor, Leminski até consegue atrair quem não costuma ler poesia. Parece que o poeta vanguardista tem sempre algo novo para oferecer e domina bem como produzir o efeito de estranhamento no seu leitor.

Para saber como isso acontece, recorremo-nos a categorização do estranhamento. A categorização consiste em agrupar "entidades semelhantes (objetos, pessoas, lugares etc.) em classes específicas" (Ferrari 31). É o processo pelo qual as ideias e os objetos são diferenciados e classificados e, portanto, um mecanismo fundamental para conhecer o fenómeno de estranhamento duma perspectiva concreta e científica.

A nossa proposta de categorização preliminar, feita à luz de linhas de pesquisa linguísticas, consiste em cinco categorias: estranhamento fonético, lexical, sintático, semântico e pragmático. Como o estranhamento causado por características da poesia concreta não se enquadra bem nelas, fizemos uma categoria específica, chamada "estranhamento visual". Assim, temos enfim seis categorias.

\subsection{Estranhamento fonético}

No nosso trabalho propomos o estranhamento fonético como a violação ou transgressão dos costumes fonéticos, a produção de dificuldades na pronúncia e/ou a quebra do ritmo da linguagem quo- 
tidiana, por meios de aliteração, assonância, onomatopeia, rima, repetição, etc.. Vejamos dois exemplos:

\section{Exemplos de estranhamento fonético}

\begin{tabular}{|c|c|c|}
\hline & Excerto poético & Técnicas de criação do estranhamento \\
\hline Exemplo 1 & $\begin{array}{l}{[\ldots]} \\
\text { qualquer som } \\
\text { qualquer um } \\
\text { pode ser tua voz } \\
\text { teu zumzumzum } \\
{[\ldots]} \\
\text { (Leminski, (B) s/p) }\end{array}$ & $\begin{array}{l}\text { Onomatopeia; } \\
\text { Rima; } \\
\text { Assonância. }\end{array}$ \\
\hline Exemplo 2 & $\begin{array}{l}\text { DISTÂNCIAS MÍNIMAS } \\
\text { um texto morcego } \\
\text { se guia por ecos } \\
\text { um texto texto cego } \\
\text { um eco anti anti anti antigo } \\
\text { um grito na parede rede rede } \\
\text { volta verde verde verde } \\
\text { com mim com com consigo } \\
\text { ouvir é ver se se se se se } \\
\text { ou se se me lhe te sigo? } \\
\text { (Leminski, (D) s/p) }\end{array}$ & $\begin{array}{l}\text { Repetição; } \\
\text { Assonância; } \\
\text { Rima }\end{array}$ \\
\hline
\end{tabular}

Fonte: As autoras

No exemplo 1, o instantâneo de estranhamento é criado pela interacção entre os sons, incluindo a assonância ("som", "um" e "zum"), a rima ("um" e "zum") e a onomatopeia ("zumzumzum").

No caso do exemplo 2, com repetições de palavras ("texto", "anti", "rede", "verde", "com" e "se"), o poeta conseguiu imitar ecos, produzindo efeito sonoro. Além disso, ainda se nota claramente a assonância na repetição do som "go" nos fins de alguns versos. Dessa forma, o poema destaca-se pelo estranhamento fonético, sobretudo quando lido em voz alta. 


\subsection{Estranhamento lexical}

O estranhamento lexical proposto por nós refere-se a estranhezas causadas pelo uso de vocábulo, incluindo estrangeirismo, termo arcaico, neologismo (por meios de hibridismo, prefixação, sufixação, entre outros), gíria, dialeto, etc. Os exemplos são:

Exemplos de estranhamento lexical

Excerto poético Técnicas de criação do estranhamento

\begin{tabular}{lll}
\hline Exemplo 3 & $\begin{array}{l}\text { PERHAPPINESS } \\
\text { (Leminski, (F) } \mathrm{s} / \mathrm{p})\end{array}$ & $\begin{array}{l}\text { Estrangeirismo; } \\
\text { Neologismo; }\end{array}$ \\
\hline Exemplo 4 & Cesta feira & $\begin{array}{l}\text { Neologismo; } \\
\text { Trocadilho; }\end{array}$ \\
& $\begin{array}{l}\text { oxalá estejam limpas } \\
\text { as roupas brancas de sexta }\end{array}$ & \\
& as roupas brancas da cesta & \\
& {$[\ldots]$} \\
& (Leminski, (B) $\mathrm{s} / \mathrm{p}$ ) & \\
& & \\
\end{tabular}

Fonte: As autoras

No exemplo 3, jogando com palavras inglesas, o poeta concebeu um poema de uma palavra só e deixa o seu leitor pensar no sentido dela. A nova palavra "Perhappiness" é construída por "perhaps" (talvez) e "happiness" (felicidade), assim possuindo o seu próprio sentido literário: a expectativa da felicidade. Além disso, observamos ainda um prefixo "per" (cada) e "pine" (desejar, esperar) nesta nova palavra. Nesse caso, temos uma outra hipótese de interpretação: "Pine (for) per happiness" (Fica à espera de cada felicidade).

O excerto 4 mostra humor logo no título "cesta feira", que troca a "sexta" da "sexta-feira" pela palavra homófona "cesta". O tal trocadilho não se destaca tanto no estranhamento fonético (no português do Brasil não faz diferença no som entre a "sexta" e a 
"cesta") como no estranhamento lexical (neologismo "cesta feira") e semântico (denotações entre a "cesta" e a "sexta").

\subsection{Estranhamento sintático}

Consideramos o estranhamento sintático como o movimento gramaticalmente anormal de constituintes sintáticos na frase, bem como o movimento não comum das frases no discurso. Normalmente, a aplicação de figuras sintáticas é uma forma de criar o efeito de estranhamento, assim como anacoluto, elipse, pleonasmo, anástrofe, desconcordância, etc..

\section{Exemplos de estranhamento sintático}

\begin{tabular}{|c|c|c|}
\hline & Excerto poético & Técnicas de criação do estranhamento \\
\hline Exemplo 5 & $\begin{array}{l}\text { quando chove, } \\
\text { eu chovo, } \\
\text { faz sol, } \\
\text { eu faço, } \\
\text { de noite, } \\
\text { anoiteço, } \\
{[\ldots \text {. . ] }} \\
\text { (Leminski, (F) s/p) }\end{array}$ & Desconcordância \\
\hline Exemplo 6 & $\begin{array}{l}\text { vazio agudo } \\
\text { ando meio } \\
\text { cheio de tudo } \\
\text { (Leminski, (F) s/p) }\end{array}$ & $\begin{array}{l}\text { Elipse; } \\
\text { Movimento anormal de componentes. }\end{array}$ \\
\hline
\end{tabular}

Fonte: As autoras

No excerto 5, é fácil notar que os verbos "chover", "fazer sol" e "anoitecer" estão conjugados em primeira pessoa do singular ("chovo", "faço sol” e "anoiteço"). No entanto, de acordo com a norma culta, eles são defectivos, já que os fenómenos da natureza não podem ser realizados por uma pessoa. As desconcordâncias aplicadas, por um lado, desfamiliarizam o leitor e mostram a lin- 
guagem informal do poema; por outro, estabelecem uma relação entre a natureza e eu lírico, pois "eu” pratico sempre uma acção de acordo com a natureza.

No exemplo 6, a elipse e a inversão são óbvias. Leminski faz um resumo adequado do sentimento da sociedade contemporânea, onde somos "cheio de tudo" por causa de várias tarefas e responsabilidades, buscando preencher os nossos próprios vazios existenciais noutros lugares. Se os constituintes sintáticos deste quase -haicai forem completos e organizados da forma normal, teríamos "ando meio/ no vazio agudo/ estou cheio de tudo". A ideia ficaria mais clara, mas perderá o efeito de estranhamento sintático.

\subsection{Estranhamento semântico}

A semântica estuda o significado de palavras, expressões e frases, como também, as suas mudanças nas denotações devido aos factores de tempo e espaço geográfico. Baseando nisso, propomos o estranhamento semântico como o estranhamento causado pela ambiguidade, polissemia, evolução etimológica e distância geográfica. Além disso, inclui novas denotações atribuídas pelo poeta às palavras, expressões e frases. Vejamos exemplos:

\section{Exemplos de estranhamento semântico}

\begin{tabular}{ll}
\hline Excerto poético & Técnicas de criação do estranhamento \\
\hline Exemplo 7 & $\begin{array}{l}\text { Estrangeirismo (ideograma japonês); } \\
\text { Nota do poeta. }\end{array}$ \\
KA W A & $\begin{array}{l}\text { 0 ideograma de kawa, "rio", em } \\
\text { japonês, pictograma de um fluxo } \\
\text { de água corrente, sempre me }\end{array}$
\end{tabular}

Cad. Trad., Florianópolis, v. 40, no 3, p. 154-186, set-dez, 2020. 
pareceu representar (na vertical) 0

esquema do haicai, o sangue dos

três versos escorrendo na parede

da página...

(Leminski, (F) s/p)

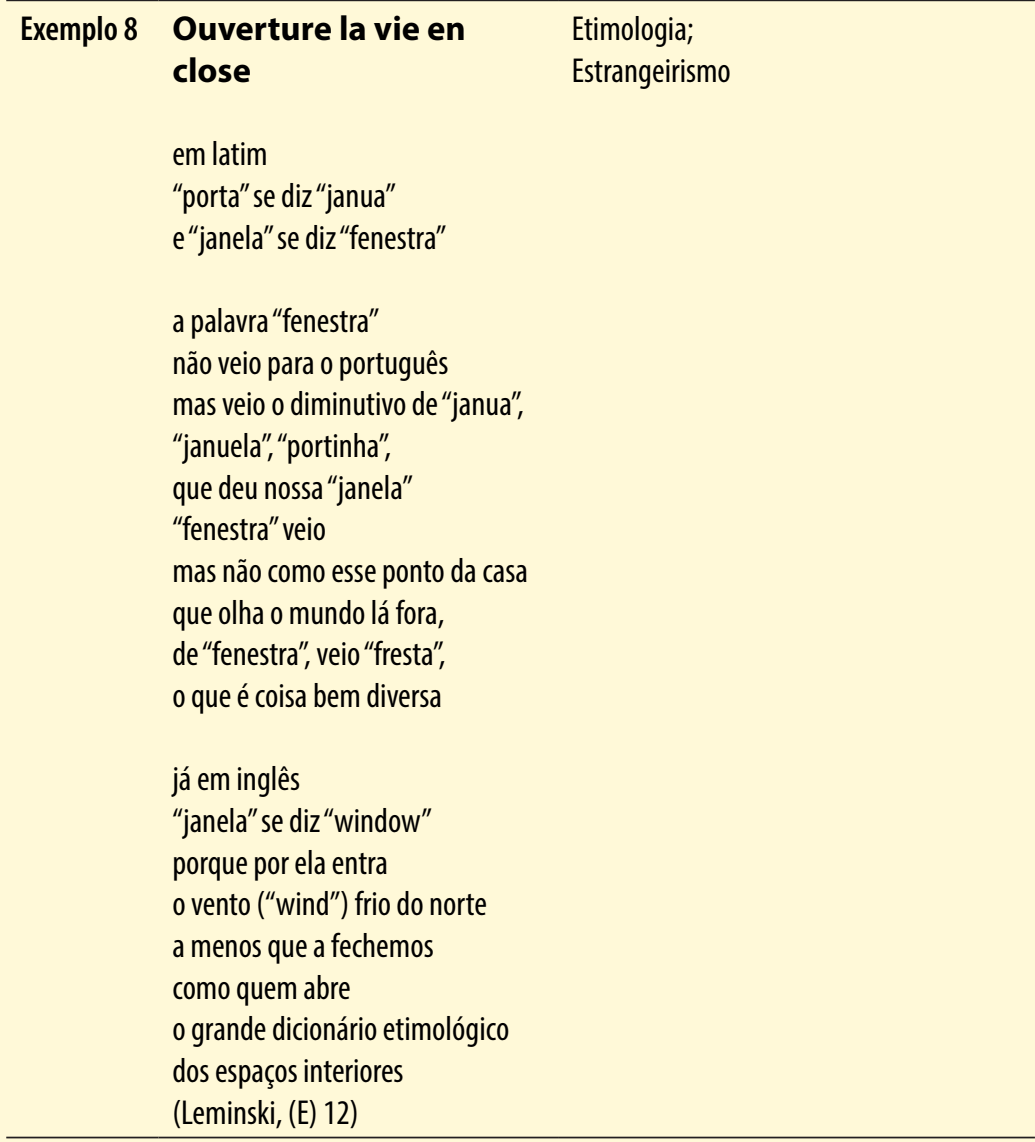

Fonte: As autoras

No exemplo 7, o uso do ideograma japonês kawa (rio) pode resultar no estranhamento visual aos leitores não familiares com caracteres japoneses ou chineses. Além disso, a nota de Leminski que faz 
parte do poema, reside outro tipo de estranhamento, o semântico. Isto é, a interpretação especial do significado de kawa: o esquema na vertical do haicai, "o sangue dos três versos escorrendo na parede da página”. Nesse caso, o kawa já carrega um novo significado.

$\mathrm{O}$ "Ouverture la vie en close" serve de bom exemplo do estranhamento na poesia leminskiana, tanto no sentido lexical, como no semântico. O título recorre ao estrangeirismo (estranhamento lexical) e contém, em francês, duas partes opostas, "ouverture" (abertura) e "la vie en close (a vida que fecha)". O poeta joga palavras com o nome da canção "la vie en rose", de forma que ocorre o paradoxo na ideia "abre-se a vida que fecha". Ao construir este poema sobre a etimologia das palavras "porta" e "janela", Leminski revela a evolução do sentido das palavras e, a partir disso, interpreta-as da sua maneira, criando estranhamento semântico ao seu leitor. Ele mostra uma nova visão em relação à subjetividade da leitura do mundo: quando se fecha, poderá haver abertura, tal como a etimologia das palavras, tal como a vida.

\subsection{Estranhamento pragmático}

A pragmática estuda significados linguísticos que se deduzem a partir de um contexto discursivo, situacional, cultural, entre outros contextos extralinguísticos. A partir disto, propomos que o estranhamento pragmático inclua estranhezas causadas pelo uso de palavras, expressões e frases com significados extralinguísticos; além disso, se trate da lógica, o humor e a filosofia do poeta, ou seja, como o locutor realiza o seu objetivo da comunicação com o mundo e com o seu interlocutor.

\section{Exemplos de estranhamento pragmático}

\begin{tabular}{lll}
\hline & Excerto poético & Técnicas de criação do estranhamento \\
\hline Exemplo 9 & eu te fiz & Tom marginal; \\
& agora & Personificação; \\
& Rima. \\
\hline
\end{tabular}

Cad. Trad., Florianópolis, v. 40, no 3, p. 154-186, set-dez, 2020. 


\begin{tabular}{|c|c|c|}
\hline & $\begin{array}{l}\text { sou teu deus } \\
\text { poema }\end{array}$ & \\
\hline & $\begin{array}{l}\text { ajoelha } \\
\text { e } \\
\text { me } \\
\text { adora } \\
(\text { Leminski, (B) s/p) }\end{array}$ & \\
\hline Exemplo 10 & $\begin{array}{l}\text { para que leda me leia } \\
\text { precisa papel de seda } \\
\text { precisa pedra e areia } \\
\text { para que leia me leda } \\
\text { precisa lenda e certeza } \\
\text { precisa ser e sereia } \\
\text { para que apenas me veja } \\
\text { pena que seja leda } \\
\text { quem quer você que me leia } \\
\text { Esse poema já foi musicado } \\
\text { duas vezes. Uma por Moraes } \\
\text { Moreira, outra por Itamar } \\
\text { Assumpção. Que tal você? } \\
\text { (Leminski, (D) s/p) }\end{array}$ & $\begin{array}{l}\text { Tom comunicativo; } \\
\text { Repetição; } \\
\text { Assonância; } \\
\text { Rima; }\end{array}$ \\
\hline
\end{tabular}

Fonte: As autoras

No exemplo 9, parece configurar-se a voz de um poeta marginal. Referimo-nos ao Marginal não no sentido de estereótipo dos poetas malditos, mas em relação à sua produção poética nos anos 70 , ao que eles se preocupavam, ou seja, a contracultura, o individualismo, a crença no corpo e na subjetividade, entre outros tópicos. Este poema demonstra um tom marginal e irreverente, em que o enunciador fala diretamente com o "poema" como se fosse uma pessoa - "sou teu deus, ajoelha e me adora". Esta relação de comunicação estabelecida entre o enunciador (eu) e o enunciatário 
(poema) implica o controlo absoluto do fazer poético da parte do poeta. Com rima se intensifica ainda o efeito de estranhamento pragmático produzido no leitor.

O exemplo 10 poder causar estranhamento pragmático é porque o poeta estabelece um diálogo direto com o seu leitor. Com uma nota inusitada que acompanha o poema no final da página: "Que tal você?", ele convida o leitor para musicar o poema. Dessa forma, deixa a obra aberta para poder realizar a desautomatização, entregando ao leitor o momento de surpresa.

\subsection{Estranhamento visual}

Na poesia concreta, aplica-se frequentemente a decomposição de palavras e frases, o aproveitamento do espaço no papel, a impressão tipográfica fora do habitual (tal como várias fontes de letras temáticas), o uso de imagens e muitas outras maneiras de organizar o poema. Sendo assim, criamos uma categoria particularizada ao estranhamento causado pelo impacto visual.

\section{Exemplos de estranhamento visual}

\begin{tabular}{lll}
\hline & Excerto poético & Técnicas de criação do estranhamento \\
\hline Exemplo 11 & aves & Decomposição das orações; \\
& de ramo & Assonância; \\
& em ramo & Rima. \\
& meu pensamento & \\
& de rima & \\
& em rima & \\
& erra \\
& até uma & \\
& que diz & \\
te amo & \\
& (Leminski, (B) $s / p)$
\end{tabular}

Cad. Trad., Florianópolis, v. 40, no 3, p. 154-186, set-dez, 2020. 


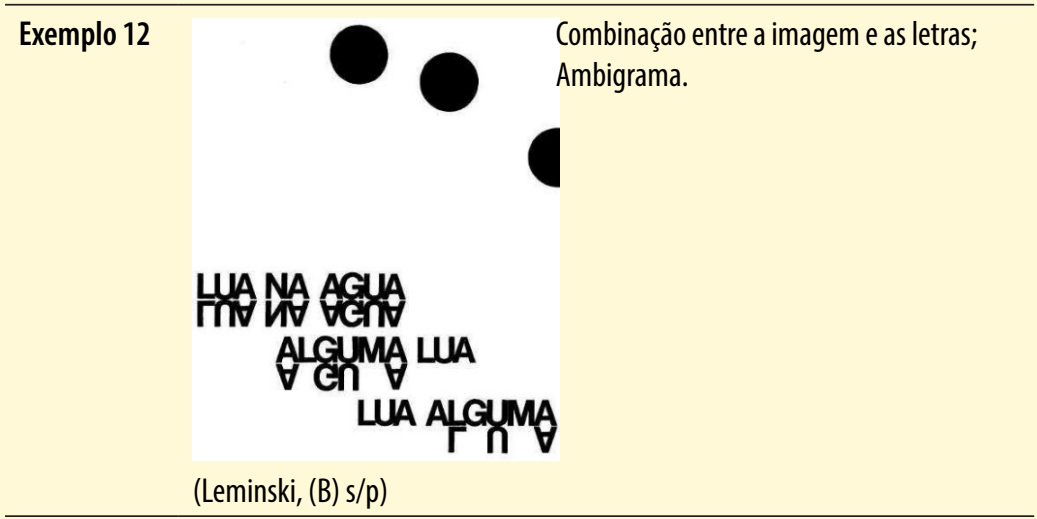

Fonte: As autoras

Normalmente, a duração da percepção deste tipo de estranhamento é mais curta do que outros, já que ele pode resultar diretamente em impacto visual sem colocar muito obstáculo diante do leitor. No exemplo 11, é fácil entender o propósito de contrafazer o movimento "de ramo em ramo" das aves, através da decomposição de orações e da organização visual.

O exemplo 12 que imita a reflexão da lua sobre a água recorre a uma combinação entre a imagem e as letras. Logo à primeira vista, o leitor já entra num contexto situacional da noite com lua e água. Na parte da imagem, denota-se o movimento da lua a desaparecer enquanto, na parte das letras, se aplica o ambigrama, isto é, uma palavra (ou palavras) podendo ser lida da mesma maneira depois de um giro de 180 graus. É de realçar que o ambigrama deste poema é fora do comum, uma vez que o reflexo das palavras na água nem sempre é completo: "lua na água - lua na água”, "alguma lua - água” e "lua alguma - lua”. Assim, quando visto, pode propiciar ainda estranhamento a quem já está habituado com esta espécie de jogo de palavras.

Em resumo, acreditamos que uma categorização adequada pode servir de ajuda no entendimento de um poema de vanguarda e, em alguns momentos, nos indica o caminho para recriar procedimentos de estranhamento na nossa tradução. Como pouco poema de Leminski foi traduzida em chinês, não tínhamos nenhuma 
tradução para consultar. Isto posto, a categorização é de extrema importância para realizarmos essas traduções. Mostraremos, na próxima secção, como ela nos ajuda no que diz respeito à recriação do estranhamento.

\section{Recriação do estranhamento na tradução poética}

Nesta secção, apresentamos como aplicamos a nossa categorização de estranhamento na tradução poética e como melhoramos a nossa tradução com técnicas de compensação. Serão apresentados 5 poemas seleccionados de Caprichos \& Relaxos (1985), Distraímos Venceremos (1987) e Toda Poesia (2013), as nossas traduções preliminares e compensadas, as principais categorias do estranhamento e as técnicas de criação e/ou compensação utilizadas. É preciso esclarecer que a "técnica de criação" aqui se refere às principais técnicas utilizadas no poema original e na tradução preliminar, enquanto a "técnica de compensação" serve para a tradução compensada. Vale ressaltar também que a "tradução preliminar" não é considerada uma tradução literal, mas uma tradução poética livre sem levar em conta as técnicas de compensação baseadas no estranhamento.

Sempre possível, identificaremos, em primeiro lugar, uma ou as principais categorias de estranhamento existentes no poema original e quais são as técnicas provavelmente utilizadas pelo poeta. Depois, tentaremos produzi-la(s) na tradução preliminar recorrendo a técnicas de recriação. Por último, compensamos a tradução preliminar de acordo com os contextos emergentes, para que os procedimentos de estranhamento sejam recriados ainda melhor. 
Exemplo de tradução 1 (ET - 1)

\begin{tabular}{|c|c|c|c|}
\hline & Poema original & Tradução preliminar & Tradução Compensada \\
\hline & $\begin{array}{l}\text { Se } \\
\text { nem } \\
\text { for } \\
\text { terra } \\
\text { Se } \\
\text { trans } \\
\text { for } \\
\text { mar } \\
\text { (Leminski, (F) } s / p \text { ) }\end{array}$ & $\begin{array}{l}\text { 如果 } \\
\text { 不是 } \\
\text { 陆地 } \\
\text { 如果 } \\
\text { 变成 } \\
\text { 海洋 }\end{array}$ & $\begin{array}{l}\text { 如果 } \\
\text { 不再是陆地, } \\
\text { 如果 } \\
\text { 变成 海洋_。 } \\
\text { (Lang 87-8) }\end{array}$ \\
\hline $\begin{array}{l}\text { Categoria do } \\
\text { estranhamento } \\
\text { (CE) }\end{array}$ & $\begin{array}{l}\text { Estranhamento visual; } \\
\text { Estranhamento } \\
\text { semântico }\end{array}$ & $\mathrm{N} / \mathrm{A}$ & $\begin{array}{l}\text { Estranhamento visual; } \\
\text { Estranhamento } \\
\text { semântico }\end{array}$ \\
\hline $\begin{array}{l}\text { Técnica de } \\
\text { criação/ } \\
\text { compensação } \\
\text { (TC) }\end{array}$ & $\begin{array}{l}\text { Decomposição da } \\
\text { palavra; } \\
\text { Antítese }\end{array}$ & $\begin{array}{l}\text { Tradução por sentido; } \\
\text { Antítese }\end{array}$ & $\begin{array}{l}\text { Modificação visual; } \\
\text { Alteração da palavra }\end{array}$ \\
\hline
\end{tabular}

Fonte: As autoras

Para o ET-1, o principal procedimento de estranhamento é visual (decomposição da palavra "transformar”), este resulta no estranhamento semântico. Portanto, o ideal é podermos recriar os dois procedimentos na nossa tradução e transmitir o sentido do poema. A nossa tradução preliminar contém a antítese entre a "terra” e o “mar” (“陆地lù dì” e “海洋hăi yáng”) e expressa a ideia de “transformar” (“变成biàn chéng”). No entanto, não está visível uma ligação entre "transformar" e "trans for mar", porque na língua chinesa a palavra “变成biàn chéng” (transformar, tornarse) não se pode decompor em “海洋hăi yáng” (mar). Nesse caso, recorremos a uma modificação visual utilizando underscore para recriar o tal estranhamento. Mantendo o sentido de "se transformar”, deixamos ao leitor espaço de imaginação: transformar em 
quê? Ao preencher o espaço por “海洋hǎi yáng”, damos, por outro lado, uma resposta: o mar. Além disso, existe ainda uma pequena alteração que trocamos “不是bú shi” (não é) por “不再是bú zài shì” (jamais, nem for) para compensar em chinês a conjugação do verbo "for" e intensificar a ideia da transformação.

\section{ET - 2}

\begin{tabular}{|c|c|c|c|}
\hline & Poema original & Tradução preliminar & Tradução Compensada \\
\hline & coração & 心 & 心 \\
\hline & EM CIMA & 向上 & 向上 $\uparrow \uparrow$ \\
\hline & escrito embaixo & 下写 & 下写 \\
\hline & FRÁGIL & 易碎 & 易碎！ \\
\hline & (Leminski, (B) s/p) & & (Lang 87) \\
\hline CE & $\begin{array}{l}\text { Estranhamento visual; } \\
\text { Estranhamento pragmático }\end{array}$ & Estranhamento pragmático & $\begin{array}{l}\text { Estranhamento visual; } \\
\text { Estranhamento pragmático }\end{array}$ \\
\hline $\mathrm{TC}$ & $\begin{array}{l}\text { Palavras maiúsculas; } \\
\text { Criação de contexto } \\
\text { situacional }\end{array}$ & $\begin{array}{l}\text { Tradução por sentido; } \\
\text { Criação de contexto } \\
\text { situacional; } \\
\text { Alteração do tamanho de } \\
\text { letras }\end{array}$ & Modificação visual; \\
\hline
\end{tabular}

Fonte: As autoras

No ET-2, o procedimento de estranhamento pragmático e o visual interagem criando um contexto situacional do dia-a-dia. O poema contém duas mensagens escritas com frequência na caixa de papelão "em cima" e "frágil" que servem para o manuseio seguro do produto armazenado. No caso em causa, o produto é o coração. Para chamar atenção e projetar um melhor efeito de estranhamento no leitor, utilizam-se palavras maiúsculas. Como em chinês não existe maiúsculas nem minúsculas, tentámos palavras maiores e menores na tradução preliminar para destacar a diferença, porém, o resultado não nos parece bom. Assim, fizemos uma alteração visual recorren- 
do a palavras a negrito. Para melhorar a tradução e causar impacto visual, acrescentámos o símbolo “ $\uparrow$ ” ao “向上 xiàng shàng” (em cima) e um ponto de exclamação a “易碎yì suì” (frágil).

\section{ET - 3}

\begin{tabular}{|c|c|c|c|}
\hline & Poema original & Tradução preliminar & Tradução Compensada \\
\hline & DISTÂNCIAS MÍNIMAS & 最近的距离 & 最近的距离 \\
\hline & $\begin{array}{l}\text { um texto morcego } \\
\text { se guia por ecos } \\
\text { um texto texto cego } \\
\text { um eco anti anti anti antigo } \\
\text { um grito na parede rede rede } \\
\text { volta verde verde verde } \\
\text { com mim com com consigo } \\
\text { ouvir é ver se se se se se } \\
\text { ou se se me lhe te sigo? } \\
\text { (Leminski, (D) s/p) }\end{array}$ & $\begin{array}{l}\text { 一篇形如蝙蝠的文章 } \\
\text { 追随着回声 } \\
\text { 一篇失明的文章文章 } \\
\text { 一串遥远远远远的回声 } \\
\text { 一声尖叫撞在墙墙 } \\
\text { 墙上 } \\
\text { 回荡着绿色绿色绿色 } \\
\text { 和我和和和你 } \\
\text { 听即是是是是所见 } \\
\text { 或是我追随着我他 } \\
\text { 你? }\end{array}$ & $\begin{array}{l}\text { 一篇形如蝙蝠的文章 } \\
\text { 追随着回响 } \\
\text { 一篇失明的文章文章 } \\
\text { 一串遥远的回响回响响 } \\
\text { 一声尖叫撞在墙上上上 } \\
\text { 荡回海浪海浪海浪 } \\
\text { 和我和和和你 } \\
\text { 听即是是是是所见 } \\
\text { 或是我追随我追随他随 } \\
\text { 你? } \\
\text { (Lang 87) }\end{array}$ \\
\hline CE & $\begin{array}{l}\text { Estranhamento } \\
\text { fonético }\end{array}$ & $\mathrm{N} / \mathrm{A}$ & Estranhamento fonético \\
\hline TC & $\begin{array}{l}\text { Repetição; } \\
\text { Rima }\end{array}$ & $\begin{array}{l}\text { Tradução por sentido; } \\
\text { Repetição }\end{array}$ & $\begin{array}{l}\text { Alteração de palavras repetidas; } \\
\text { Alteração da rima }\end{array}$ \\
\hline
\end{tabular}

Fonte: As autoras

Como explicado na última secção, o principal estranhamento do ET-3 é o fonético. Demonstra a imitação dos ecos através das repetições dos "texto" "anti" "rede" "com" e "se", junto com rimas entre "morcego", "eco" e "cego", entre "antigo", "consigo" e "sigo" e, ainda, "parede", "rede" e "verde". Se traduzirmos por sentido, uma tradução possível será como a nossa preliminar, assim perdendo rimas no segundo verso (terminado em “声shēng”), quarto (terminado em “声shēng”) e sexto verso (terminado em “色sè”). Considerando as diferenças sintática e semântica entre a língua por- 
tuguesa e a chinesa, mudámos na tradução compensada as palavras repetidas e a rima. No segundo verso, trocámos “回声huí shēng” (eco) por uma palavra sinónima “回响huí xiăng” para rimar com o primeiro e terceiro verso. No sexto verso, substituímos “绿色lü sè” (verde) por “海浪hăi làng” (onda), assim ganhando rima com os primeiros cinco versos e, consequentemente, o significado do verso mudou completamente.

\section{ET - 4}

\begin{tabular}{|c|c|c|c|}
\hline & Poema original & Tradução preliminar & Tradução Compensada \\
\hline & aves & 鸟儿 & 鸟儿 \\
\hline & de ramo & 从树枝 & 从树枝 \\
\hline & em ramo & 到树枝 & 到树枝 \\
\hline & meu pensamento & 我的思想 & 我所想所思 \\
\hline & de rima & 从韵脚 & 从韵脚 \\
\hline & em rima & 到韵脚 & 到韵脚 \\
\hline & erra & 飘摇 & 飘摇 \\
\hline & até uma & 直至某处 & 直至某处 \\
\hline & que diz & 它说 & 它说 \\
\hline & te amo & 我爱你 & 你是我的诗 \\
\hline & (Leminski, (B) s/p) & & (Lang 88) \\
\hline CE & $\begin{array}{l}\text { Estranhamento visual; } \\
\text { Estranhamento fonético }\end{array}$ & Estranhamento visual & $\begin{array}{l}\text { Estranhamento visual; } \\
\text { Estranhamento fonético }\end{array}$ \\
\hline TC & $\begin{array}{l}\text { Decomposição de } \\
\text { orações; } \\
\text { Rima. }\end{array}$ & $\begin{array}{l}\text { Decomposição de orações; } \\
\text { Tradução por sentido }\end{array}$ & Alteração da rima \\
\hline
\end{tabular}

Fonte: As autoras

O poema original do ET-4 é relatado num tom romântico e possui estranhamento tanto visual como fonético. Com a ajuda das orações decompostas e a organização visual semelhante à original, conseguimos a nossa tradução preliminar. Contudo, não se recriou o estranhamento fonético, perdendo rimas em dois versos. Na tradução compensada, “我的思想wǒ de sī xiăng” (meu pensamento) foi mudado 
para “我所想所思wǒ suǒ xiăng suǒ sī” (o que penso) enquanto “我 爱你wǒ ài nı̌” (te amo) foi alterado por “你是我的诗nǐ shì wǒ de shī" (tu és a minha poesia), de modo que esses dois versos rimam com os segundo e terceiro. Assim se recria o estranhamento fonético.

ET - 5

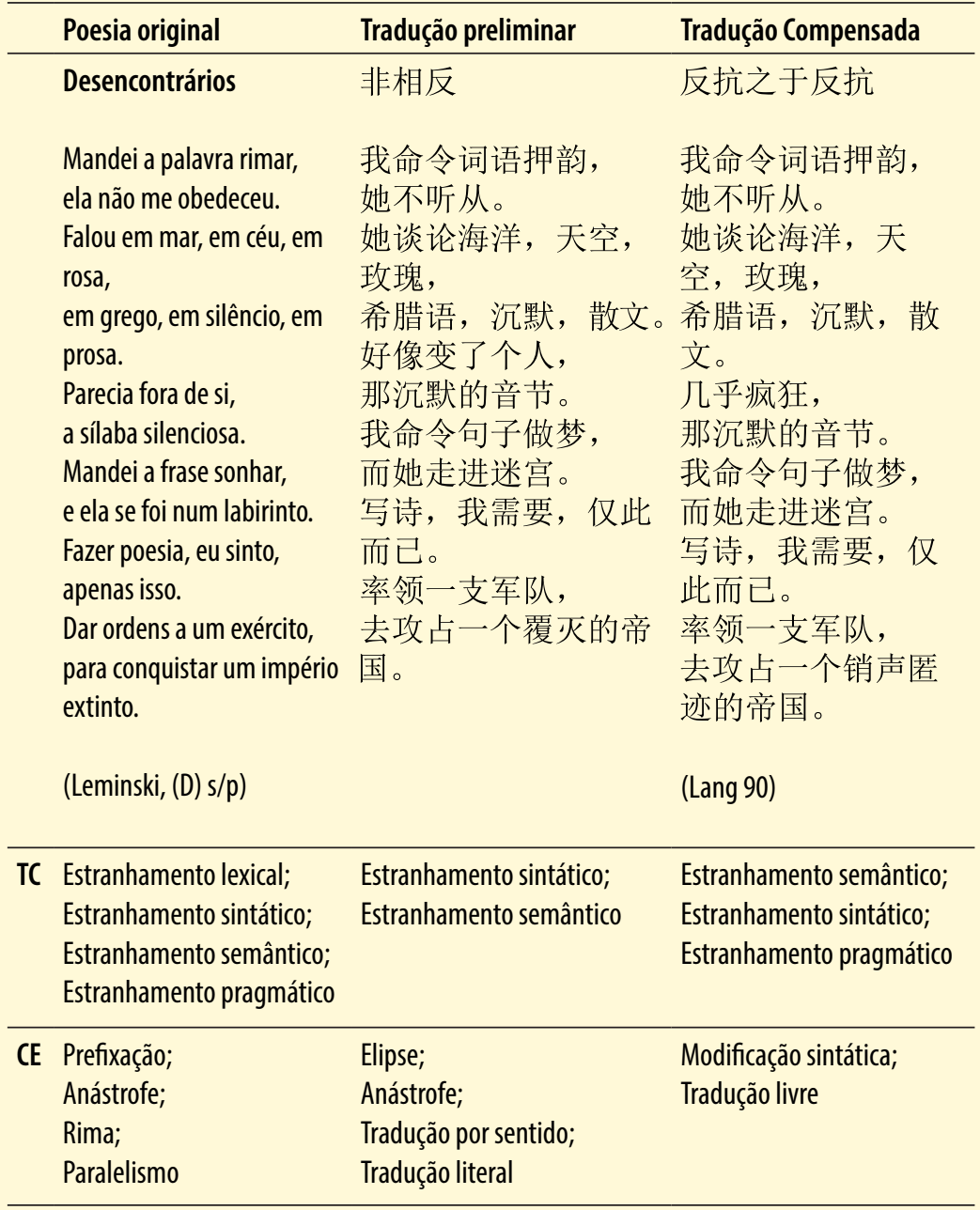

Fonte: As autoras

Cad. Trad., Florianópolis, v. 40, n⿳ 3, p. 154-186, set-dez, 2020. 
O poema "Desencontrários" é outro exercício da metalinguagem do poeta, manifestando a sua opinião sobre o fazer poesia: o exercício da poesia é como uma luta com as palavras. As palavras podem escapar do domínio do poeta e criar a sua própria lógica ("ela não me obedeceu", "parecia fora de si" e "se foi num labirinto") e "eu" sinto "dar ordens a um exército". Eis o elemento de surpresa e a beleza desses versos, na contradição entre a ordem do poeta e a loucura do poema. A relação difícil entre os opostos é implicada logo no título do poema, "desencontrários", um neologismo que causa estranhamento tanto lexical como semântico. No início, traduzimo-lo literalmente, “非相反fēi xiāng făn” (não contrário). Quando feita a tradução preliminar, perguntávamo-nos: será que a palavra primativa é "encontro" ou "contrário"? O que quer dizer "des-en-contrário-s"? Depois das muitas pesquisas relacionadas, descobrimos o mistério do título: o desencontro dos contrários. Ou seja, é justamente esta luta (desencontro; oposição) entre o poeta e a sua arte (os contrários). Portanto, mudámos completamente o título traduzido na tradução compensada “反抗之于 反抗făn kàng zhī yú făn kàng” (o contrário contra o contrário). Como existe a diferença entre a formação de palavras entre as duas línguas, o estranhamento lexical perdeu-se inevitavelmente, de certa forma, mantém-se o estranhamento semântico. No poema original, através do paralelismo (os primeiros versos das duas estrofes) e da anástrofe ("parecia fora de si / a sílaba silenciosa"), nota-se ainda o estranhamento sintático que tentámos manter na tradução.

\section{Considerações finais}

O presente trabalho tem como objetivo propor uma categorização do estranhamento particularizada à poesia de Paulo Leminski, e aplicá-la na nossa tradução de seus poemas do português para o chinês.

Para tal, debatemos, em primeiro lugar, a conotação do estranhamento tanto no contexto literário como na tradução literária. Além disso, foi feita uma apresentação sucinta de Leminski e do 
estranhamento na sua poesia. A partir dos poemas leminskianos, levantamos a nossa inédita proposta de categorização do estranhamento, incluindo seis categorias, nomeadamente: estranhamento fonético, lexical, sintático, semântico, pragmático e visual. Esta categorização foi exemplificada com 12 poemas e excertos poéticos de Leminski, e aplicada nas traduções de cinco poemas seus.

Entendemos que, o processo de tradução orientado pela estratégia de estranhamento foi uma maneira eficaz de testar e melhorar a categorização. Foi também nesse processo em que nos ocorreram novas reflexões e questões. Inicialmente, encontramos que, muitas vezes, em um poema, existem vários procedimentos de estranhamento. Eles convivem e estão interligados. Por exemplo, o estranhamento lexical e o semântico aparecem frequentemente juntos. Na tradução, quando se muda um, muda-se o outro. Além disso, é bastante difícil tratar separadamente do estranhamento semântico e do pragmático, devido à interface entre os dois. Será que o estranhamento pragmático ainda existiria sem base semântica?

E ainda, se pensarmos pela perspectiva do leitor, ele sente o efeito de estranhamento como um todo, ou melhor, ele lê o poema como um todo em vez de separar os elementos nem se concentrar em um nível só. Isso implica que, para o tradutor, é importante ter sensibilidade para descobrir o novo, mas manter também um equilíbrio entre o estranhamento e outros elementos do poema. Um poema consiste de elementos mais e menos traduzíveis. Assim, a recriação do estranhamento não é uma questão de possibilidade, mas de grau. Quer dizer, o tradutor deve ponderar os ganhos e perdas na tradução. Por exemplo, devido à diferença do sistema fonético entre as duas línguas, no ET 3, para ganharmos nos ecos e rimas na LA, perdemos na tradução uma parte do sentido original. No ET 4, além do estranhamento visual, tentamos recriar o fonético, assim mudando o significado de alguns versos. A ligação bem estreita entre a forma e o conteúdo na poesia leminskiana solicita que seja construída uma outra arquitetura linguística no texto de chegada. Em resposta ao espírito e à força da poesia leminskiana, o tradutor necessita aceitar a impossibilidade de ser o outro, mas 
ao mesmo tempo, deve produzir o estranhamento necessário com o objetivo de "imaginar (e criar) chinesidades leminskianas", tal como defende Jatobá (145).

Para concluir, gostaríamos de realçar que as nossas traduções feitas, sendo apenas uma das possibilidades de interpretar os poemas originais, buscavam recriar o efeito de estranhamento, e recusavam-se a existir sempre na automatização. Quanto à nossa proposta de categorização, ela procurava analisar o estranhamento e a poesia leminskiana por uma nova perspectiva, nunca pretendendo ser absoluta nem automatizada. Mesmo que seja formulada a partir da poesia leminskiana, suponhamos que ela possa ser aplicada em análises e traduções dos outros poetas e obras. Esperamos vê-la desenvolvida em futuros trabalhos. Defendemos toda a liberdade dos leitores, parafraseando Leminski ((B) s/p):

Aqui, traduções para lerem, em silêncio,

Traduções para fazer, a várias maneiras.

E questões, comentários, sugestões, para deixar.

Quais, quais, é com você, parceiro.

\section{Referências}

Chklovski, V. "A arte como procedimento". Teoria da literatura: Formalistas russos, editado por Toledo, D. O., 3.ed., Porto Alegre: Globo, 1976, pp.39-56.

Coleridge, Samuel; Coleridge, Henry Nelson. Biographia Literaria. New York: Wiley \& Putnam, 1847. 
Fabre, Mardilê Friedrich. "Contagem das sílabas poéticas.”. Recanto das Letras. 21 mar 2013. web. 31/03/2019. Disponível em: https://www.recantodasletras. com.br/teorialiteraria/254742.

Favaretto, Celso. Tropicália: Alegoria, alegria. 3.ed. São Paulo: Ateliê Editorial, 2000.

Ferrari, Lilian. Introdução à linguística cognitiva. São Paulo: Editora Contexto, 2011.

Gazoni, Fernando. A Poética de Aristóteles: Tradução e comentários. (Dissertação de Mestrado em Filosofia). Faculdade de Filosofia, Letras e Ciências Humanas, Universidade de São Paulo, 2006.

Jatobá, Júlio. "Poéticas do Traduzir a, na e para a China: uma proposta". Cadernos de Tradução, 39 (especial), 2019: 120-147. DOI: https://doi.org/10.5007/21757968.2019v39nespp120. 20/02/2020. Disponível em: https://periodicos.ufsc.br/ index.php/traducao/article/view/2175-7968.2019v39nespp120/42143.

Lang, Sida. “保罗·莱明斯基的诗” [Poemas de Paulo Leminski]. ChineseWestern Poetry. 1. 72. (2019): 85-92.

Leminski, Paulo. (a). Anseios crípticos: Anseios teóricos: Peripécias de um investigador do sentido no torvelinho das formas e das idéias. Vol. 1, Curitiba: Edições Criar, 1986.

Leminski, Paulo. (b). Caprichos e relaxos. 3.ed. São Paulo: Brasiliense, 1985.

Leminski, Paulo. (c). Cruz e Sousa: o negro branco. Vol. 24. São Paulo: Brasiliense, 1983.

Leminski, Paulo. (d). Distraímos venceremos. 2.ed. São Paulo: Brasiliense, 1987.

Leminski, Paulo. (e). La vie en close. 5.ed. São Paulo: Brasiliense, 1994.

Leminski, Paulo. (f). Toda poesia. São Paulo: Companhia das Letras, 2013. 
Leminski, Paulo. (g). Vida: Cruz e Sousa, Bashô, Jesus e Trótski. Porto Alegre: Sulina, 1988.

Leminski, Paulo; Bonvicino, Régis. Envie meu dicionário: Cartas e alguma crítica. São Paulo: Edtora 34, 1999.

Longino, Dionísio. Do sublime. Tradução do grego, introdução e comentário de Marta Isabel de Oliveira Várzeas. Coimbra: Imprensa da Universidade de Coimbra, 2015.

Marques, Fabrício. Aço em flor: A poesia de Paulo Leminski. São Paulo: Autêntica, 2001.

Moriconi, Italo. Os cem melhores poemas brasileiros do século. São Paulo: Objetiva, 2001.

Muratori, Ludovico. Della perfetta poesia italiana. Milão: Marzorati, 1971.

Nida, Eugene. Toward a Science of Translation. Leida: Brill, 1964.

Robinson, Douglas. Estrangement and the Somatics of Literature: Tolstoy, Shklovsky, Brecht. Baltimore, Maryland: JHU Press, 2008.

Salgueiro, Wilberth. "Tempos de Paulo Leminski: entre estória e história." Contexto - Revista do Programa de Pós-Graduação em Letras, no.13, 2006.

Schleiermacher, Friedrich. "Sobre os diferentes métodos da tradução.", Clássicos da teoria da tradução, editado por Heidermann, Werner., vol.1: Alemão/ Português, 2.ed., 2010, Florianópolis: UFSC, pp.38-101.

Venuti, Lawrence. The Translator's Invisibility: a History of Translation Studies. Oxfordshire: Taylor \& Francis, 2004.

Wordsworth, William, and Samuel Coleridge. Lyrical Ballads. S.L: Woodstock Books, 1990. 
Wu Lifu. 西方文论选. [Antologia da teoria literária ocidental]. Shanghai: Shanghai Translation Publishing House, 1979

Recebido em: 02/03/2020

Aceito em: 20/05/2020

Publicado em setembro de 2020

Sisa Lang. E-mail: veralang@sina.com. ORCID: https://orcid.org/0000-00030309-7314.

Yuqi Sun. E-mail: sunyuqi@um.edu.mo. ORCID: https://orcid.org/0000-00027310-1385. 